\title{
4. THE RELIEF OF THE OCEANIC BASEMENT AND THE STRUCTURE OF THE FRONT OF THE ACCRETIONARY COMPLEX IN THE REGION OF SITES 541, 542, AND 5431
}

\author{
A. Mauffret, Groupe d'Etude de la Marge Continentale, Département de Géologie Dynamique, \\ Université Pierre et Marie Curie \\ G. K. Westbrook, Department of Geological Sciences, University of Durham \\ M. Truchan, Center for Marine Crustal Studies, Gulf Research and Development Company \\ and \\ J. Ladd, Lamont-Doherty Geological Observatory of Columbia University ${ }^{2}$
}

\begin{abstract}
The shape of the surface of the oceanic igneous basement beneath the accretionary complex is produced by superimposition of ridges and troughs, related to WNW-trending fracture zones, upon the downward flexure of lithosphere into the subduction zones. The ocean crust is Upper Cretaceous, as determined by identification of oceanic magnetic anomalies and the polarity of magnetic anomalies associated with the fracture zones. The magnetic polarity boundary associated with Anomaly 34 lies a little to the west of Site 543. The forward growth of the accretionary complex is related to the amount of sediment accreted. This is in turn broadly related to the thickness of the sediment on the ocean floor, which is locally controlled by basement topography. Consequently, there are significant changes in position and trend of the front of the complex where it crosses ridges and troughs. Growth at the front of the complex is controlled by the level at which a décollement forms in the sediments, and this is only indirectly related to sediment thickness. This décollement shows local stratigraphic control, so small changes in basement topography beneath the décollement do not influence the accretionary complex. Seismic velocities in the accretionary complex and in the sediments on the ocean floor, determined from sonobuoys, are not sufficiently unambiguous to show whether there are, in the velocity structure of the sediments, any major changes from that which would be expected from greater compaction with depth.
\end{abstract}

\section{INTRODUCTION}

The principal basement feature in the region of the Leg 78A drill sites is the depression of the oceanic basement as it passes into the subduction zone beneath the Lesser Antilles island arc. The oceanic basement reaches a depth of about $17 \mathrm{~km}$ before passing beneath the crystalline crust of the Caribbean Plate's leading edge. The axis of the depression lying along the edge of the crystalline Caribbean Plate is marked by a Bouguer gravityanomaly minimum, by truncation of magnetic-anomaly trends associated with the ocean crust, and by a significant increase in seismicity (Officer et al., 1959; Westbrook, 1975; Westbrook, 1982; Bowin, 1976; Westbrook et al., this volume; Stein et al., 1982). It deepens from north to south. There is active normal faulting, shown by seismicity (Stein et al., 1982), associated with the bending down of the oceanic basement; the faults, which can be seen on seismic reflection profiles, are particularly well shown on the outer rise NE of the Puerto Rico Trench (Marlow et al., 1974; Bunce et al., 1974). A relatively recent SEABEAM survey has shown that these faults run roughly parallel to the trench axis (V. Renard, personal communication, 1981).

\footnotetext{
${ }^{1}$ Biju-Duval, B., Moore, J. C., et al., Init. Repts. DSDP, Vol. 78A: Washington (U.S. Govt, Printing Office)

2 Addresses: (Mauffret) Groupe d'Etude de la Marge Continentale, Département de Géologie Dynamique, Université Pierre et Marie Curie, 4 place Jussieu, 75230 Paris, Cedex 05, France; (Westbrook) Department of Geological Sciences, University of Durham, DH1 3LE, England; (Truchan) Center For Marine Crustal Studies, Gulf Research and Development Co., One Blue Hill Plaza, Pearl River, NY 10965; (Ladd) Lamont-Doherty Geological Observatory of Columbia University, Palisades, NY 10964.
}

Running WNW through the region are several ridges and troughs associated with fracture zones in the oceanic lithosphere. The most obvious ridges are the Barracuda Ridge and the Tiburon Rise. They provide local control of sediment thickness, and have some direct deformational effect on the accretionary complex (Westbrook, 1982).

It is characteristic of the accretionary complex north of the Tiburon Rise that (1) the oceanward slope of the complex is very low $\left(<1.5^{\circ}\right)$; (2) deformation is generally on too small a scale for significant structure to be seen on seismic sections, giving a chaotic appearance to the deformed material; and (3) the deformed material of the accretionary complex is underlain by a sequence of undeformed sediments. This last feature was first noted by Chase and Bunce (1969). Peter and Westbrook (1976) showed that the undeformed sediment on the ocean crust beneath the complex extended at least $30 \mathrm{~km}$ from the front, and most recently it has been shown to extend at least $75 \mathrm{~km}$ from the front (Westbrook et al., 1982; Westbrook et al., this volume).

In this chapter, the results of several Lamont-Doherty cruises-particularly C1602, C1909, and V3107-are described in relation to the features outlined above. The positions of selected profiles from these cruises are shown in Figure 1, and line drawings of some of these are shown in Figure 2. Seismic reflection tracks in the area are shown in Figure 3.

\section{OCEANIC BASEMENT}

Depth to basement in the area of the Leg 78A sites is shown in Figure 3. There is an overall deepening to the 


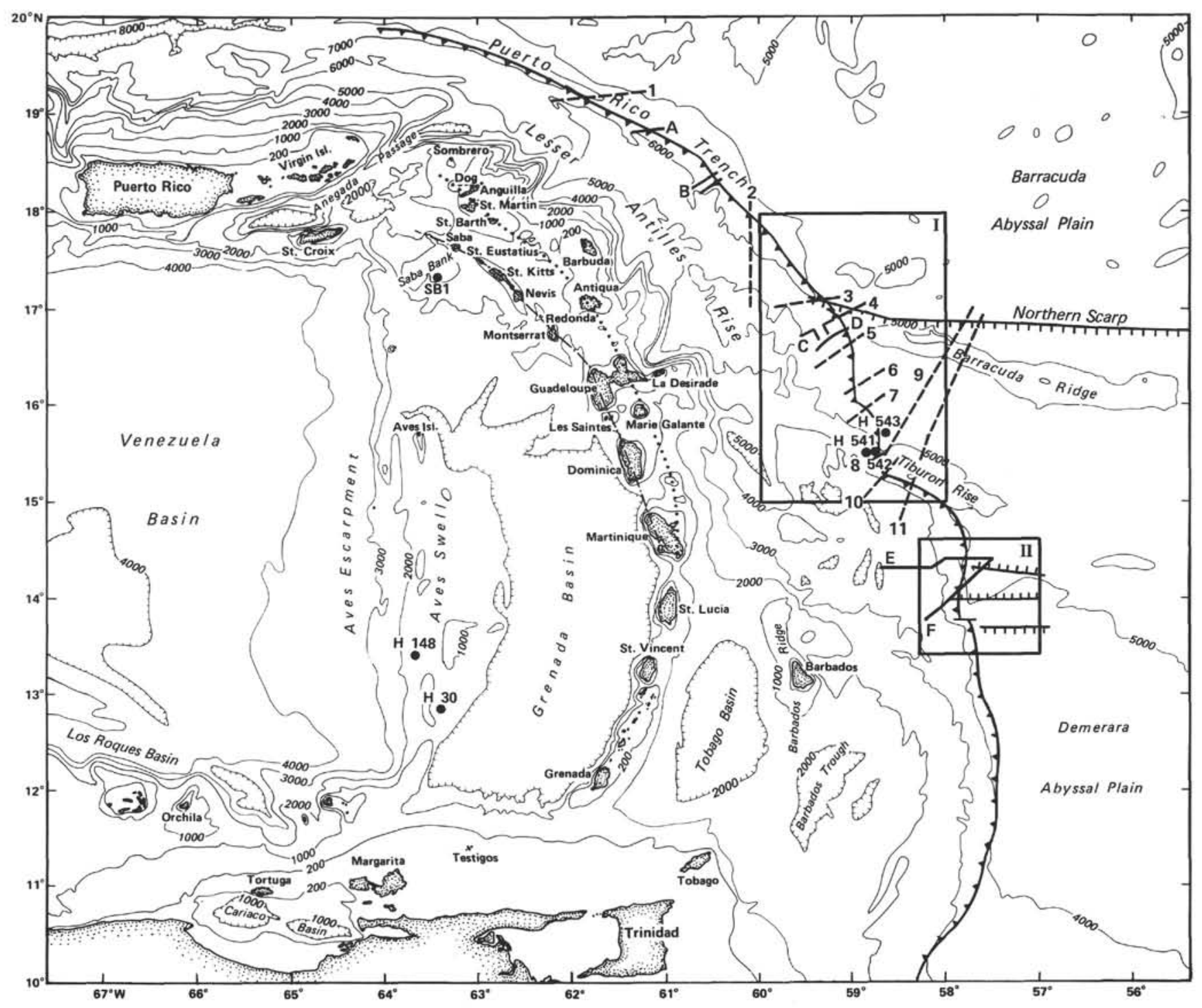

Figure 1. Location map. Numbers 1-11 refer to cross sections shown in Figure 2. Letters A-F refer to seismic sections shown in Figures 5, 8, 9, 10,

12 , and 13. Frame I shows the area of Figures 3, 4, 6, and 7. Frame II shows the area of Figure 14. Bathymetric contours at 1000-m intervals.

west, continuation of which is shown well by the Bouguer gravity anomaly map (Fig. 4). This map is part of a larger map compiled for the Ocean Margin Drilling Project Synthesis of the eastern Caribbean (Westbrook and Jackson, in press). The correction density used was 2100 $\mathrm{kg} \cdot \mathrm{m}^{-3}$, which is the density that produces the least correlation between anomaly and topography on the accretionary complex and therefore gives the best correction for the density contrast between seawater and the sediments forming the complex. About 30 to $40 \mathrm{~km}$ east of the deformation front (the dotted line on Fig. 4), the outer trench rise can be traced where it causes high points on ridges and saddles in troughs. Several normal faults offset the seaward flank of the northeast Puerto Rico Trench (Marlow et al., 1974), but farther south these faults are buried by the accretionary prism (Fig. 2, sections 1 and 2, and Fig. 5). Also prominent are WNWtrending features, particularly the Barracuda Ridge and the Tiburon Rise. Another narrow ridge (A, Fig. 3) lies north of the Barracuda Ridge, separated from it by a prominent but locally narrow trough, along which runs the Barracuda Fracture Zone. At about $16^{\circ} \mathrm{N}$ (C, Fig. 3) lies another less prominent, WNW-trending ridge with a trough to the south of it. This is also the site of another fracture zone, as shown by the magnetic anomaly pattern (Fig. 6). The Bouguer anomaly map shows that these features continue a significant distance beneath the complex to the axis of tectonic depression (lithospheric subduction trace), where they give rise to culminations along the axis of the gravity minimum.

The magnetic anomalies show the presence of three major fracture zones: one just north of the Barracuda Ridge, one just south of the $16^{\circ} \mathrm{N}$ ridge, and another just south of the Tiburon Rise. Changes in the polarities of the anomalies along the fracture zones reflect changes in the sense of crust magnetization on either side of the fracture zones. The map of Figure 6 is from a larger one prepared for the Ocean Margin Drilling Project Synthe- 


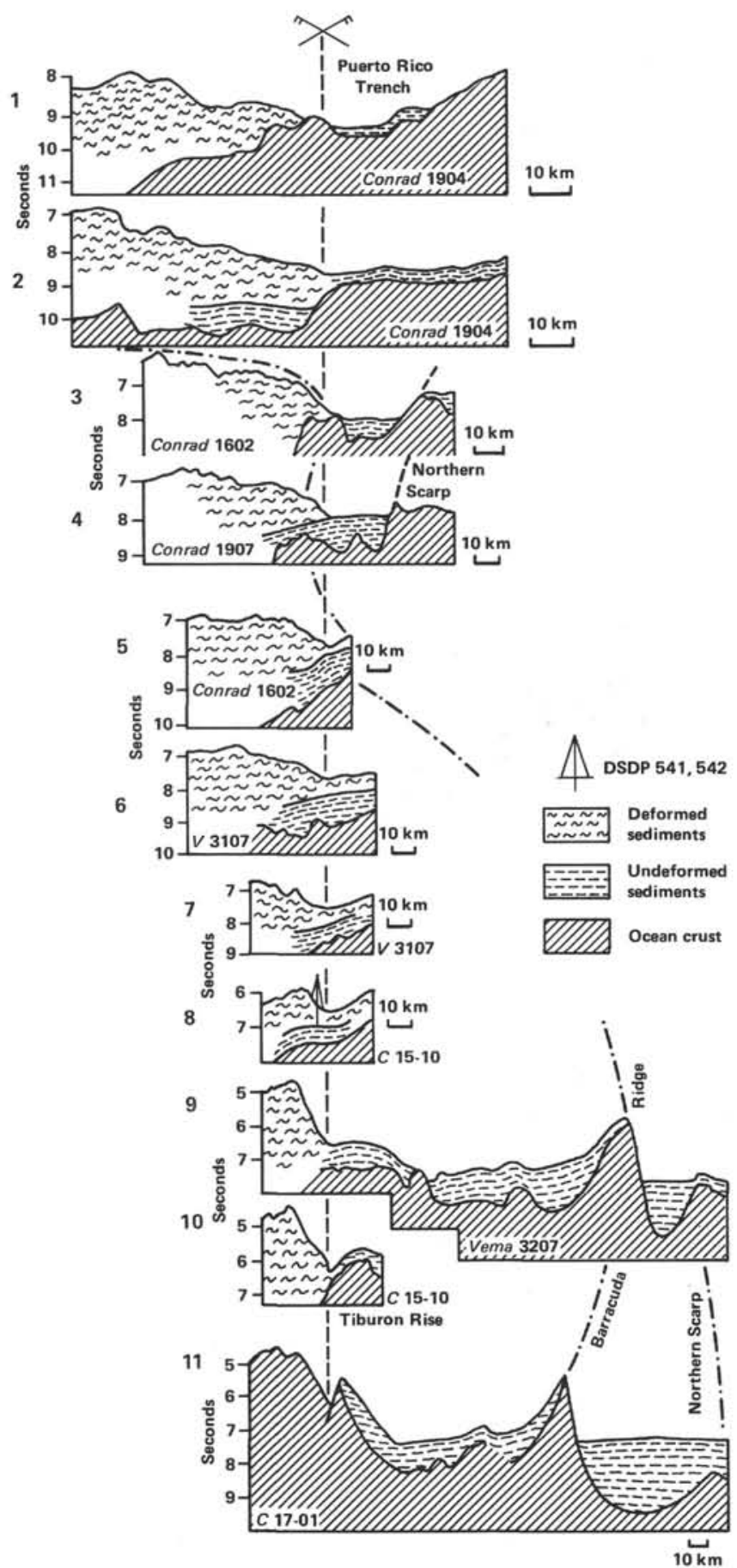

Figure 2. Cross sections of the deformation front. All sections except 1 and 2 have a similar scale and a nearly normal strike to the front. Locations in Figure 1. The deep Barracuda Trough is bounded by the Barracuda Ridge and the Northern Scarp (Figs. 9 and 10). The Barracuda Ridge loses its surface morphologic expression westward beneath the accretionary complex (Sections 3 and 4). The slope at the front of the accretionary complex is locally steeper along the southern margin of the Tiburon Rise (Sections 9, 10, and 11).

sis of the eastern Caribbean (Westbrook, in press, a), and from this map and profiles used in its preparation, it was possible to identify Anomaly 34 and subsequent anomalies (Westbrook et al., this volume; Westbrook, in press, b). Anomaly 34 is particularly easy to recognize because of the large extent of normally magnetized crust to the west of it. The positions of the oceanic anomalies are shown in Figure 6, and it can be seen that Site 543 is on negatively magnetized crust lying between Anomalies 34 and 33. This is compatible with the lower Campanian assignment based on the nannofossils present in the core closest to the basement (Bergen, this volume), and the occurrence of exclusively negatively magnetized basalt samples from the basement (Wilson, this volume). The close proximity of Anomaly 34 also explains why some positively magnetized samples were found.

\section{Barracuda Ridge and Trough}

The Barracuda Ridge and Trough are an asymmetric pair of features. The steep north scarp of the Barracuda Ridge composes the southern margin of the Barracuda Trough, which, east of $59^{\circ} \mathrm{W}$, lies beneath the Barracuda Abyssal Plain (Birch, 1970; Paitson et al., 1964).

The northern margin of the Barracuda Trough is formed by a scarp (Northern Scarp) which is buried in the east (Fig. 2, sections 10 and 11), but which emerges progressively westward and outcrops near $58.5^{\circ} \mathrm{W}$ (Fig. 2 , sections 3 and 4). The Barracuda Ridge loses a great part of its elevation before it passes beneath the accretionary complex (Fig. 2, sections 3 and 4, and Fig. 3), but its continuation as a narrower ridge can be traced some 100 km WNW (Schubert, 1974; Fig. 2, section 2, and Fig. 3). The reason for the change in trend in the Barracuda Ridge from WNW to W near $57^{\circ} \mathrm{W}$ is not yet clearly understood, although it is probably related to a change in spreading direction.

\section{Barracuda Fracture Zone}

Running along the Barracuda Trough and at the base of the Northern Scarp is the Barracuda Fracture Zone. Anomaly 33 is left-laterally offset across it by $210 \mathrm{~km}$. The Barracuda Ridge may be a south-flanking ridge (Stein et al., 1982) of a type similar to the South Vema Ridge (van Andel et al., 1971; Bonatti, 1978). Although well defined west of $58^{\circ} \mathrm{W}$, the position of the fracture zone is not so clear in the broader part of the Barracuda Trough beneath the Barracuda Abyssal Plain and its further continuation to the east.

The Barracuda Fracture Zone could be the continuation to the $15^{\circ} 20 \mathrm{~N}$ Fracture Zone (Collette et al., 1974; Peter et al., 1973; Peter and Westbrook, 1976), which has a $155-\mathrm{km}$ left-lateral offset at the Mid-Atlantic Ridge and has been renamed la Désirade Fracture Zone (Le Douaran and Francheteau, 1981; Olivet et al., in press). Alternatively, the Barracuda Fracture Zone could run into the Royal Trough (Collette et al., 1974), which lies a little to the north of the $15^{\circ} 20 \mathrm{~N}$ Fracture Zone and does not reach the Mid-Atlantic Ridge. Several reorganizations of spreading took place during the Tertiary, and complete continuity between Cretaceous and present fracture zones is not necessarily expected.

\section{Tiburon Rise}

The Tiburon Rise runs parallel to the Barracuda Ridge. East of $57^{\circ} \mathrm{W}$, where it becomes a subsurface feature, it 


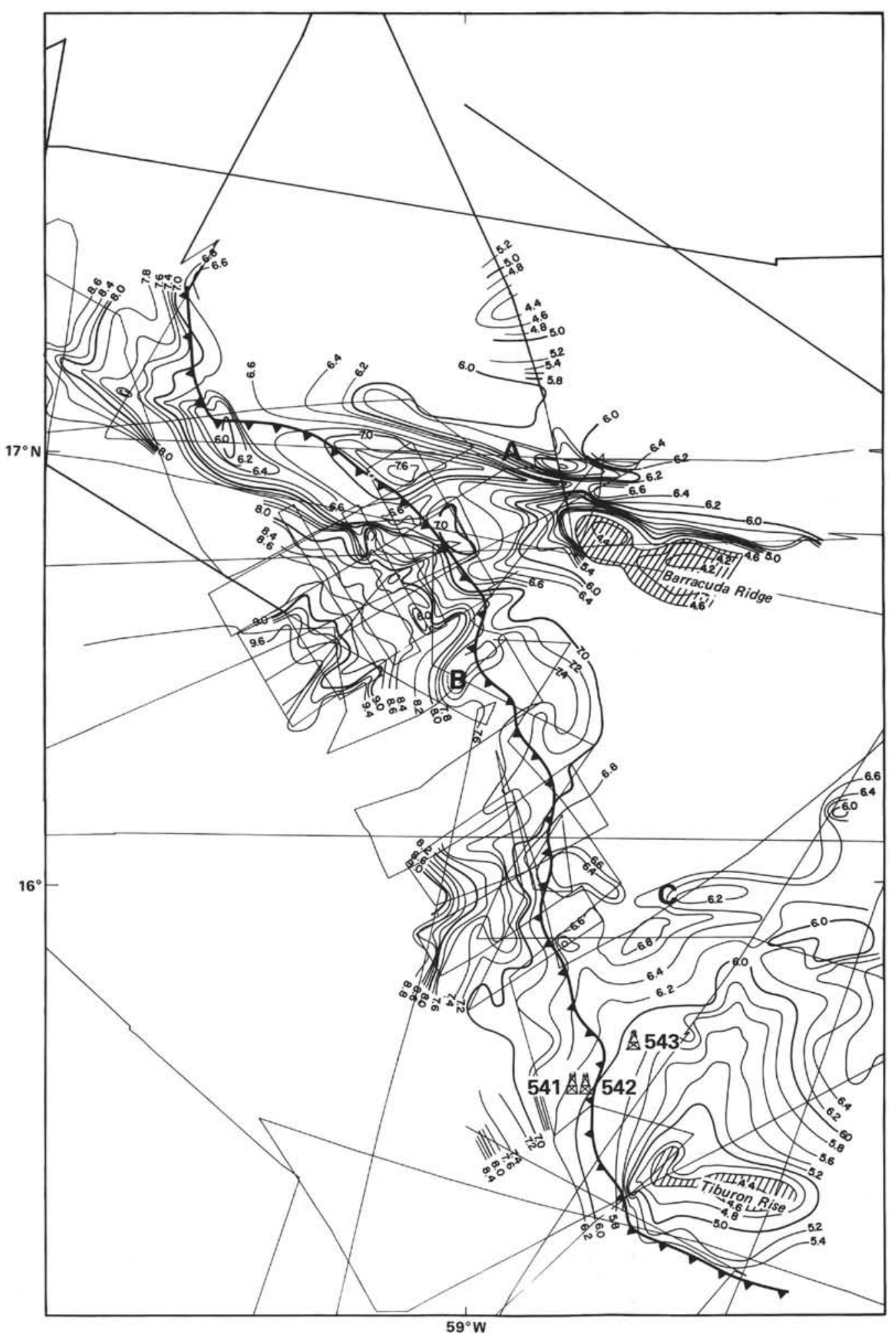

Figure 3. Depth to basement $(\mathrm{km})$ for the area in Frame I, Figure 1. The velocities from sonobuoys have been used to convert reflection time to $\mathrm{km}$. The map shows westward deepening of oceanic basement under the accretionary complex. The Barracuda Ridge and Tiburon Rise are clearly shown, as are the Northern Scarp of the Barracuda Trough (A), a small basement high beneath the deformation front (B), and a ridge on the northern margin of an unnamed fracture zone $(\mathrm{C})$. 


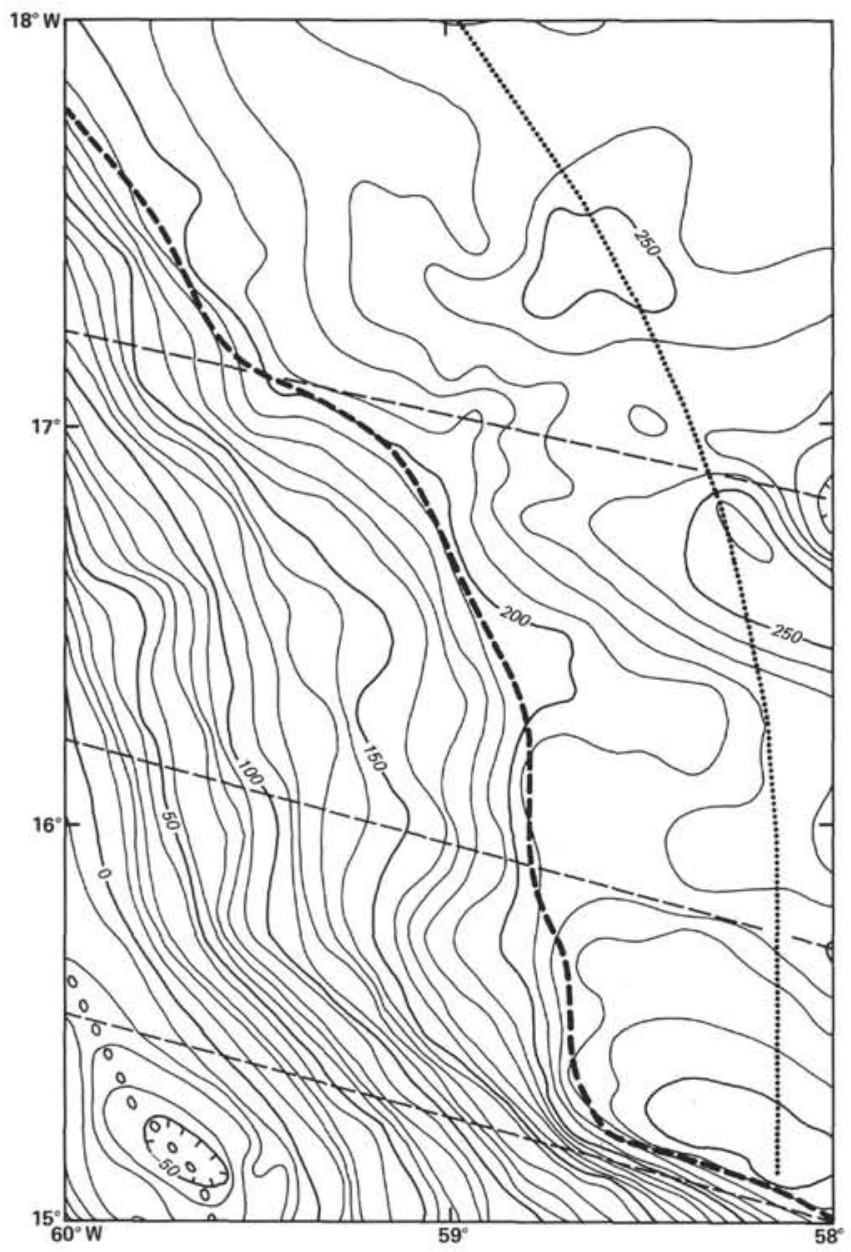

Figure 4. Bouguer gravity anomaly map for the area in Frame I, Figure 1. Correction density of $2100 \mathrm{~kg} \cdot \mathrm{m}^{-3}$; contours at $10 \mathrm{mgal}$ intervals. The westward-decreasing gradient reflects the depression of the ocean crust as it enters the subduction zone beneath the Lesser Antilles. The WNW extensions of the Barracuda Ridge and Tiburon Rise are shown by the inflections of contours over them. The front of the accretionary complex is shown by the heavy dashed line. The position of the principal minimum of the negative gravity anomaly associated with the subduction zone is shown by a line of zeroes. The position of the outer trench is shown by a dotted line. Thin dashed lines represent the positions of fracture zones identified from magnetic anomalies (see Fig. 6).

changes trend from WNW to W (Fig. 1 and Fig. 2, sections 10 and 11). The rise is asymmetric, and has a deep trough along the southern flank.

\section{ACCRETIONARY COMPLEX}

The structure of the accretionary complex is discussed at length elsewhere in this volume. Here, the main features are summarized and related to the geophysical data presented.

The accretionary complex thickens westward as a function of increasing basement depth and increasing surface elevation produced by the accretion process (Fig. 7). The initial slope of the complex is usually gentle $\left(<1.5^{\circ}\right)$, has a ridged surface with fairly fine-scale relief-shown well by GLORIA (Belderson et al., this volume) and SEABEAM (Fontas et al., this volume)and has a wavelength of betwen 0.5 and $2 \mathrm{~km}$.

This contrasts with the southern part of the complex, where the sedimentary layer involved in the deformation is thicker and the structures broader, forming large anticlines underlain by thrusts, as shown by SEABEAM, seismic profiles (Biju-Duval et al., 1982; Chase and Bunce, 1969; Peter and Westbrook, 1976), and GLORIA (Stride et al., 1982).

The most striking feature in the seismic sections is the sequence of undeformed reflectors lying beneath the deformed zone (Chase and Bunce, 1969; Marlow et al., 1974; Peter and Westbrook, 1976). The top of this sequence has been interpreted as a décollement surface (Biju-Duval et al., 1978; Westbrook, 1982), and its lateral continuation into the undeformed sediments on the ocean floor lies at between one fourth and one half the thickness of the sediments beneath the seabed. So typically only about a third of the ocean floor sediments are accreted onto the complex at its front. A décollement is widespread beneath the accretionary complex (Westbrook et al., this volume), but is locally absent, particularly north of the Barracuda Ridge. It is known to extend landward, with some disturbance, as far as $75 \mathrm{~km}$ from the front of the complex (Westbrook et al., 1982; Westbrook et al., this volume). The functioning of the intrasediment décollement, and the thinness of the complex, are only possible if there are very low shear stresses along the décollement; such conditions can be brought about if pore fluid pressures are close to lithostatic pressure, as indicated by back-pressure built up during the emplacement of casing in Hole 542B (see site report for Site 542, this volume). The décollement can be seen on most of the profiles depicted in Figures 2, 5, and 8-10.

A point of importance is whether the level at which the décollement occurs is controlled by a significant change in the properties of the rock above and below it, or by very local changes. Unfortunately, no cores were obtained in Hole 543 (on the abyssal plain) exactly at the level of the horizon thought to form the décollement under the accretionary prism. There are, however, small but significant differences in density and shear strength between the rocks overlying and underlying the reflector that appears to form the décollement (Marlow et al., this volume). Many measurements of seismic velocities in the upper crust have been made in the region, using sonobuoys. The sonobuoy data (Fig. 11) were correlated with the seismic profiles to examine the distribution of seismic velocities with respect to the major structural features of the complex, described above. Velocities determined in the sediments are usually interval velocities derived using the wide-angle reflections from prominent reflectors, such as the basement surface and the décollement. Velocities in the basement come from refracted arrivals. Both sets of velocities are susceptible to error arising from the dips of the reflectors and refractors. The values given here are not corrected for dip, but the lines were run parallel to strike.

The sonobuoy data show that the sediments above the décollement have a lower seismic velocity than the 


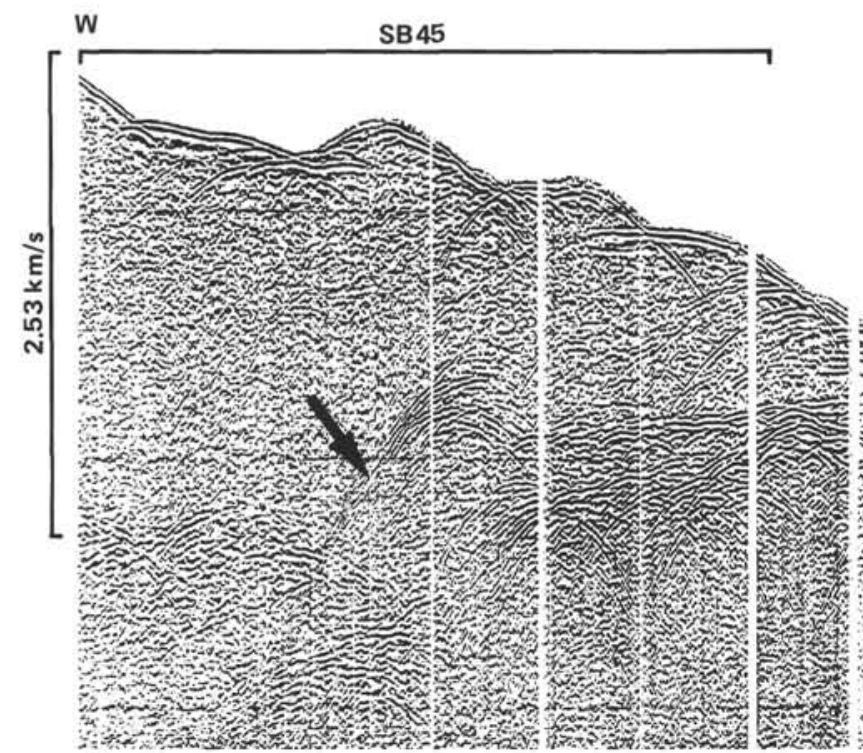

A

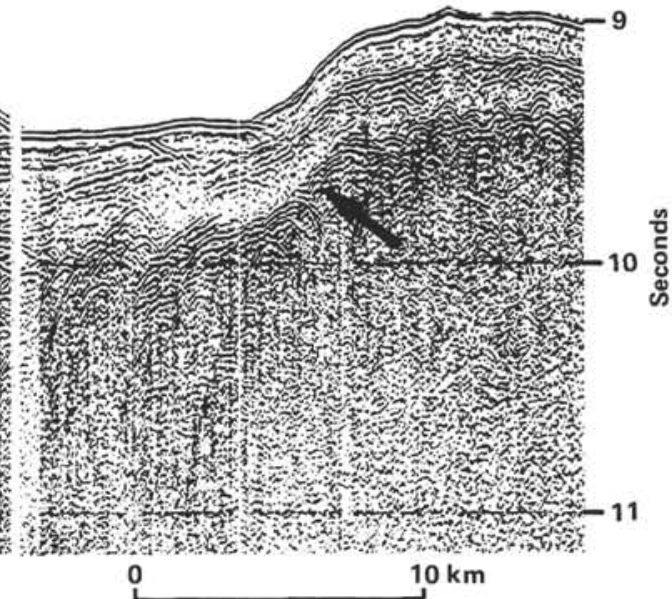

$10 \mathrm{~km}$

Figure 5. Seismic section (along line A, Fig. 1) across the Puerto Rico Trench, NNE of Barbuda. The basement on the seaward flank of the trench is offset by a scarp, probably of fault origin; a similar scarp can be seen beneath the accretionary wedge. The deformed layers have compressional velocities of $2.53 \mathrm{~km} / \mathrm{s}$ (SB45).

sediments below it, and that a similar bipartite division exists in the undeformed sediment on the ocean floor. In some cases, however, consistent reflections from the décollement were not obtained, so only the interval velocity between the surface and the basement was derived. The results as presented must be treated with some caution, because the method of deriving the interval velocities assumed that the velocity in each layer was constant, changing only at the layer boundaries-whereas a velocity distribution in which velocity increases linearly with depth fits the data equally well. A surface velocity of $1.6 \mathrm{~km} \cdot \mathrm{s}^{-1}$ and a velocity gradient of $0.7 \mathrm{~km} \cdot \mathrm{s}^{-1} / \mathrm{km}$ predicts the interval velocities derived from the sonobuoys reasonably well, including the interval velocities above and below the décollement reflector. The model of continuous velocity increase with depth implies no substantial differences in properties above and below the décollement, other than those arising from increasing compaction with depth, and suggests that the reflector is produced by a vertically local change in density and/or velocity. It also is in accord with measurements of sonic velocity on the cores from Hole 543 (Marlow et al., this volume). The variability between sonobuoy measurements precludes a more detailed analysis showing variations in seismic velocity related to compaction in the accretionary prism.

\section{Along-Strike Variation in Structure}

Most of the along-strike variation in structure is related to the influence of basement relief. Immediately obvious in this regard is the deformation front (see also Belderson et al., this volume), which bends in response to basement relief and sediment thickness (Westbrook, 1982). Large " $\mathrm{S}$ " bends occur across the Tiburon Rise and Barracuda Ridge. The bend at $17^{\circ} \mathrm{N}$ (Fig. 7) is not related wholly to Barracuda Ridge, but also in part to the Northern Scarp (Fig. 1), which marks the boundary between a hummocky abyssal plain and the thick sediment infilling the Barracuda Trough.

The sediment thickness map (Fig. 7) shows that the front is relatively farther west in areas of thinner sediments (see the influence of a small high at $16^{\circ} 30 \mathrm{~N}$; B, Fig. 7).

On the accretionary complex above the extensions of the Barracuda Ridge, Northern Scarp, and Tiburon Rise, there are northward-facing slopes which reflect the change in elevation of the complex in response to the change of sediment thickness across these features. The ridges, in addition to controlling the supply to sediment to the complex, also appear to have a more direct dynamic influence: they approach the complex obliquely and "snowplough" the complex on their southern flanks (Westbrook, 1982). This is particularly clear on the southern flank of the Tiburon Rise, where the complex is more intensely deformed and the initial slope is much steeper than along the front of the complex elsewhere (Fig. 2). This effect also occurs to a lesser extent on the southern flank of the Barracuda Ridge.

North of $17^{\circ} \mathrm{N}$, sediments are generally thinner than to the south. Deformation in the complex appears to be more intense (the complex is much more acoustically opaque), and in places a clear décollement is not developed within sediments above the basement.

South of the Tiburon Rise, the sediments are much thicker than in the region to the north, and appear to include a significant terrigenous component. The deformation is more gentle, and although a décollement occurs beneath the accretionary complex, it is not along such a sharply defined layer as in the Leg $78 \mathrm{~A}$ region. Multichannel lines 14 and 15 from Conrad 1904 (Figs. 12 and 13) show the structure in the deep trough on the southern flank of the Tiburon Rise (Fig. 14). Broad 


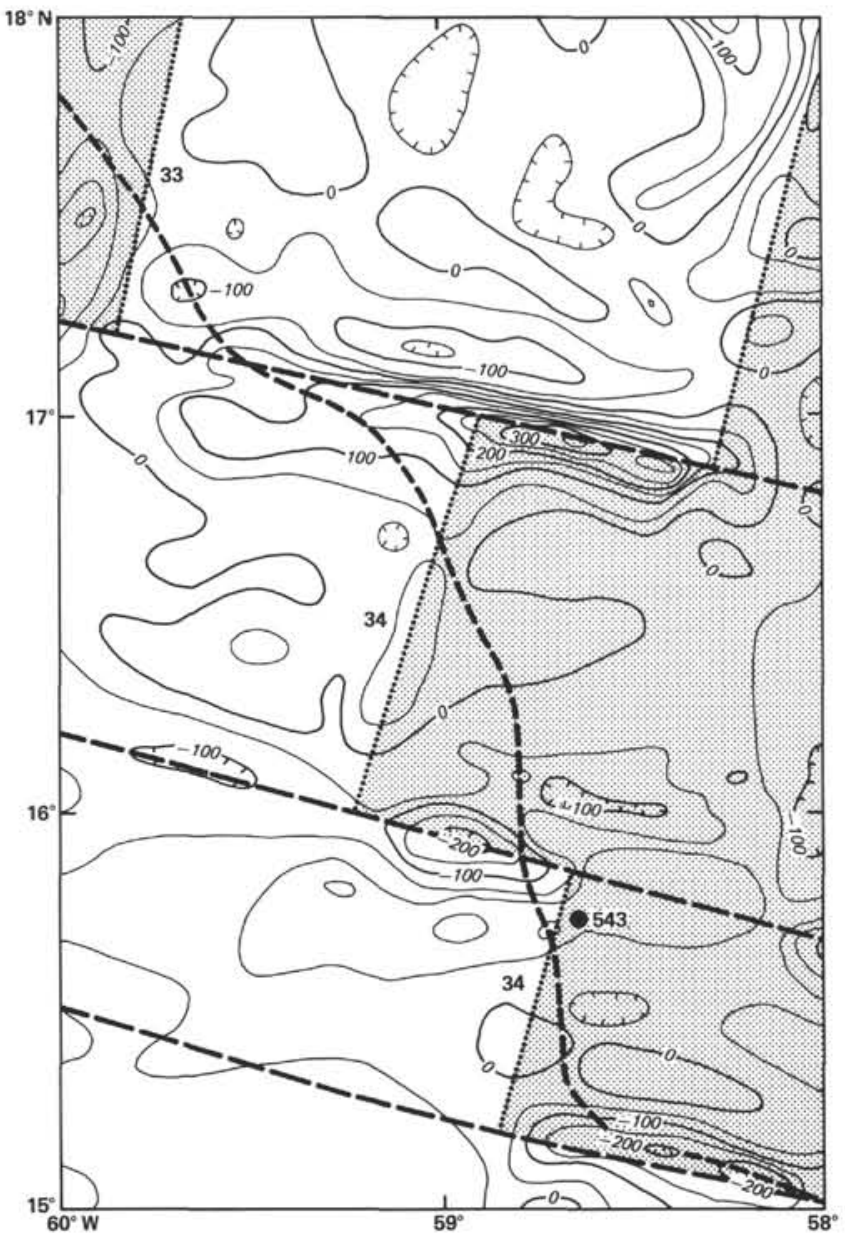

Figure 6. Map of total-field magnetic anomalies for the area of Frame I, Figure 1. Contours at 50-gamma intervals. Boundaries between positively and negatively magnetized crust are shown by dotted lines. Negatively magnetized crust is shaded. Fracture zones are shown by heavy diagonal, long-dashed lines. Oceanic magnetic anomalies are identifed by their numbers. Site 543 is shown by filled circle. The front of the accretionary complex is indicated by a heavy short-dashed line.

folds and thrusts are developed, and a clear westwarddipping reflector extends deep into the complex (Fig. 12) above a décollement separating it from comparatively undisturbed sedimentary horizons beneath. Line 14, running obliquely across the flank of a basement high already described by Peter and Westbrook (1976) and Westbrook (1982), shows the basement rising step by step to the south (Figs. 13 and 14). The initial décollement surface appears to be stratigraphically controlled at the same level in both sections, so that the initial volume of sediment accreted to the front of the complex is locally independent of variations in sediment thickness beneath the décollement.

\section{CONCLUSIONS}

The particular tectonic and sedimentary environment in which the Leg 78A holes were drilled owes much to the influence of ridges and troughs related to transform faults on the Cretaceous Mid-Atlantic Ridge. The lower Campanian chronostratigraphic classification of the base- ment of Site 543 correlates well with the age derived from the pattern of oceanic magnetic anomalies.

The develoment of a sharply defined décollement surface is characteristic of this region of the forearc, where sediments are predominantly pelagic and of moderate thickness. There is no unambiguous evidence for any major difference in the physical properties of the rocks above and below the décollement surface. Deformation in the accretionary complex is related to the thickness of the sediment layer accreted: it is more intense if the layer is thinner. The ridges and troughs in the oceanic basement, by controlling the thickness of sediment entering the complex, control the position of the deformation front and the elevation of the complex. They also deform the complex as a consequence of their oblique convergence with the complex.

\section{ACKNOWLEDGMENTS}

This work was conducted while all the authors were at LamontDoherty Geological Observatory, supported in part by a contract from JOI, Inc. A. Mauffret is grateful to the Centre National de la Recherche Scientifique for support during several visits to Lamont. This is Groupe d'Etude de la Marge Continentale contribution GEMC ERA 605, number 256.

\section{REFERENCES}

Biju-Duval, B., Le Quellec, P., Mascle, A., Renard, V., and Valery, P., 1982. Multibeam bathymetric survey and high resolution seismic investigations on the Barbados Ridge complex (eastern Carribean): A key to the knowledge and interpretation of an accretionary wedge. Tectonophysics, 80:275-304.

Biju-Duval, B., Mascle, A., Montadert, L., and Wanneson, J., 1978. Seismic investigations in the Colombia, Venezuela, and Grenada basins, and on the Barbados Ridge for future IPOD Drilling. Geol. Mijnbouw., 57:105-116.

Birch, F. S., 1970. The Barracuda fault zone in the western North Atlantic: geological and geophysical studies. Deep Sea Res., 17:847-859.

Bonatti, E., 1978. Vertical tectonism in oceanic fracture zones. Earth Planet. Sci. Lett., 37:369-379.

Bowin, C. O., 1976. The Caribbean gravity field and plate tectonics. Geol. Soc. Am. Spec. Pap., 169:79.

Bunce, E. T., Phillips, J. D., and Chase, R. L., 1974. Geophysical study of the Antilles Outer Ridge, Puerto Rico Trench, and northeast margin of Caribbean Sea. Am. Assoc. Petrol. Geol. Bull., 58: 106-123.

Chase, R. L., and Bunce, E. T., 1969. Underthrusting of the eastern margin of the Antilles by the floor of the western North Atlantic ocean and the origin of the Barbados Ridge. J. Geophys. Res., 74: 1413-1420.

Collette, B., Schouten, H., Rutten, K., Slootweg, A. P., 1974. Structure of the Mid-Atlantic Ridge province between $12^{\circ}$ and $18^{\circ} \mathrm{N}$. Mar. Geophys. Res. 2:163-179.

Le Douaran, S., and Francheteau, J., 1981. Axial depth anomalies from $10^{\circ}$ to $50^{\circ}$ North along the Mid-Atlantic Ridge. Correlation with other mantle properties. Earth Planet. Sci. Lett., 54:29-47.

Marlow, M. S., Garrison, L. E., Martin, R. G., Trumbull, J. V. A., and Cooper, A., 1974. Tectonic transition zone in the northeastern Caribbean. J. Res. U.S. Geol. Surv., 2:289-302.

Officer, C. B., Ewing, J., Hennion, J. F., Harkrider, D. G., and Miller, P. E., 1959. Geophysical investigations in the eastern Caribbean-Venezuela Basin, Antilles island arc and Puerto Rico Trench. Geol. Soc. Am. Bull., 68:359-378.

Olivet, J. L., Bonnin, J., Beuzart, P., and Auzende, J. M., in press. Atlantique Nord et central. Synthèse cinématique. Spec. Publ. CNEXO (Brest).

Paitson, L., Savit, C. H., Blue, M., and Knox, W. A., 1964. Reflection survey at Barracuda fault. Geophysics, 29:941-950.

Peter, G., Lattimore, R. K., De Wald, O. E., and Merrill, G., 1973. Development of the Mid-Atlantic Ridge east of the Lesser Antilles island arc. Nature Phys. Sci., 245:129-131. 
Peter, G., and Westbrook, G. K., 1976. Tectonics of southwestern North Atlantic and Barbados Ridge complex. Am. Assoc. Petr. Geol. Bull., 60:1078-1106.

Schubert, C., 1974. Seafloor tectonics east of the northern Lesser Antilles. Abst. Seventh Carib. Geol. Conf., pp. 62-63. (Abstract)

Stein, S., Engeln, J. F., Wiens, D. A., Speed, R. C., and Fujita, K., 1982. Subduction seismicity and tectonics in the Lesser Antilles arc. J. Geophys. Res., 87:8642-8664.

Stride, A. H., Belderson, R. H., and Kenyon, N. H., 1982. Structural grain, mud volcanoes, and other features on the Barbados Ridge complex revealed by GLORIA long-range side-scan sonar. Mar. Geol., 49:187-196.

van Andel, Tj. H., Von Herzen, R. P., and Phillips, J. D., 1971. The Vema Fracture Zone and the tectonics of transverse shear zone in oceanic crustal plates. Mar. Geophys. Res., 1:261-283.

Westbrook, G. K., 1975. The structure of the crust and upper mantle in the region of Barbados and the Lesser Antilles. Geophys, J. R. Astr. Soc., 43:201-242.

1982. The Barbados Ridge complex: tectonics of a mature forearc system. In Leggett, J. K. (Ed.), Trench and Forearc Geology. Sedimentation and Tectonics in Modern and Ancient Subduction Zones. Spec. Publ. Geol. Soc. Lond., 10:275-290. in press, a. Magnetic anomaly map of the eastern Caribbean. In Speed, R. C., Biju-Duval, B., Ladd, J. W., Mascle, A., Moore, J. C., et al. (Eds.), Atlas of Geology and Geophysics of the Lesser Antilles Arc System and Surrounding Terrains: Washington, D.C. (J. Thompson \& Co.).

in press, b. Oceanic magnetic anomalies and fracture zones. In Speed, R. C., Biju-Duval, B., Ladd, J. W., Mascle, A., Moore, J. C., et al. (Eds.), Atlas of Geology and Geophysics of the Lesser Antilles Arc System and Surrounding Terrains: Washington, D.C. (J. Thompson \& Co.).

Westbrook, G. K., and Jackson, R. J., in press. Gravity anomalies. In Speed, R. C., Biju-Duval, B., Ladd, J. W., Mascle, A., Moore, J. C., et al. (Eds.), Atlas of Geology and Geophysics of the Lesser Antilles Arc System and Surrounding Terrains: Washington, D.C. (J. Thompson \& Co.).

Westbrook, G. K., Smith, M. J., Peacock, J. H., and Poulter, M., 1982. Extensive underthrusting of undeformed sediment beneath the accretionary complex of the Lesser Antilles subduction zone. Nature Lond., 300:625-628.

Date of Initial Receipt: September 21, 1982 Date of Acceptance: September 29, 1983 


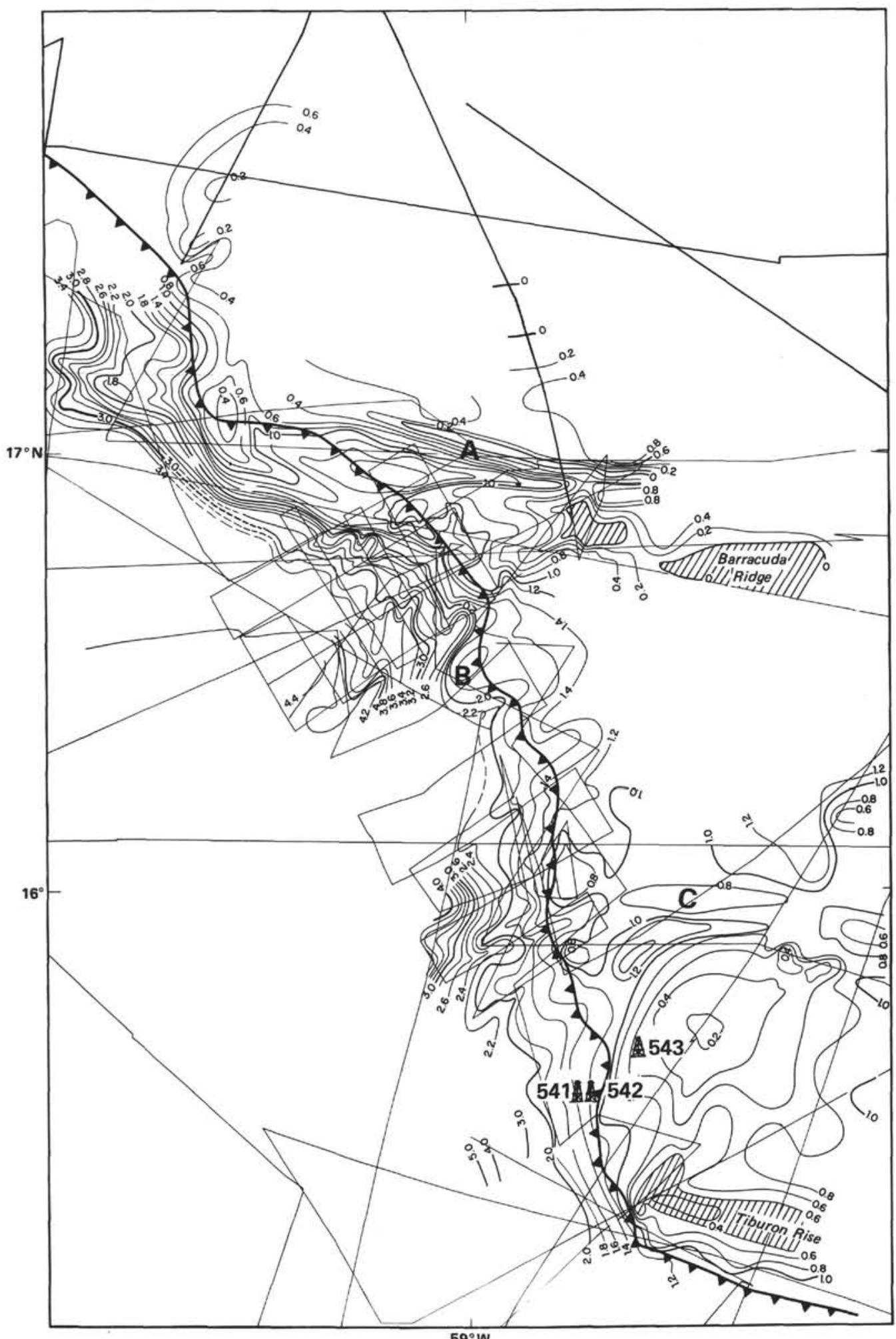

$59^{\circ} \mathrm{W}$

Figure 7. Sediment thickness map for the area in Frame I, Figure 1, showing that bending of the deformation front is linked closely to thickness of sediment layer east of the defc:mation front. (Thickness in $\mathrm{km}$.) Where the layer is thicker, the front is shifted to the east. The influence of the Tiburon Rise and Barracuda Ridge/ Northern Scarp is clearly shown by north-facing fronts of the accretionary complex. Just at the contact of the front, the Barracuda Trough has a thick $(1.6 \mathrm{~km})$ infilling. $\mathrm{A}=$ Northern Scarp, B = small basement high, $\mathrm{C}=$ ridge flanking northern side of unnamed fracture zone. 


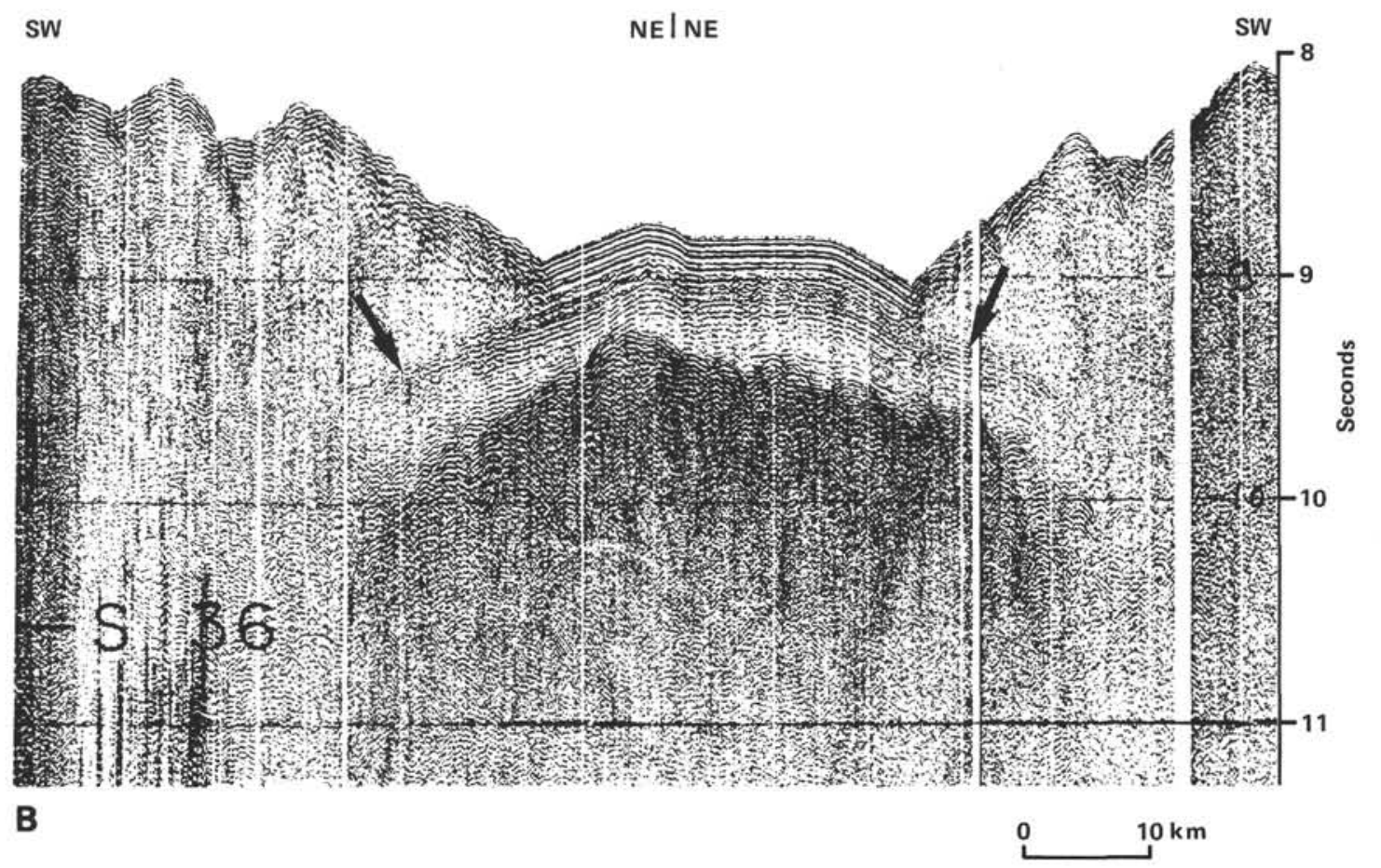

Figure 8. Two cross sections (along line B, Fig. 1) of the front of the accretionary complex NE of Barbuda, showing the décollement (black arrows).
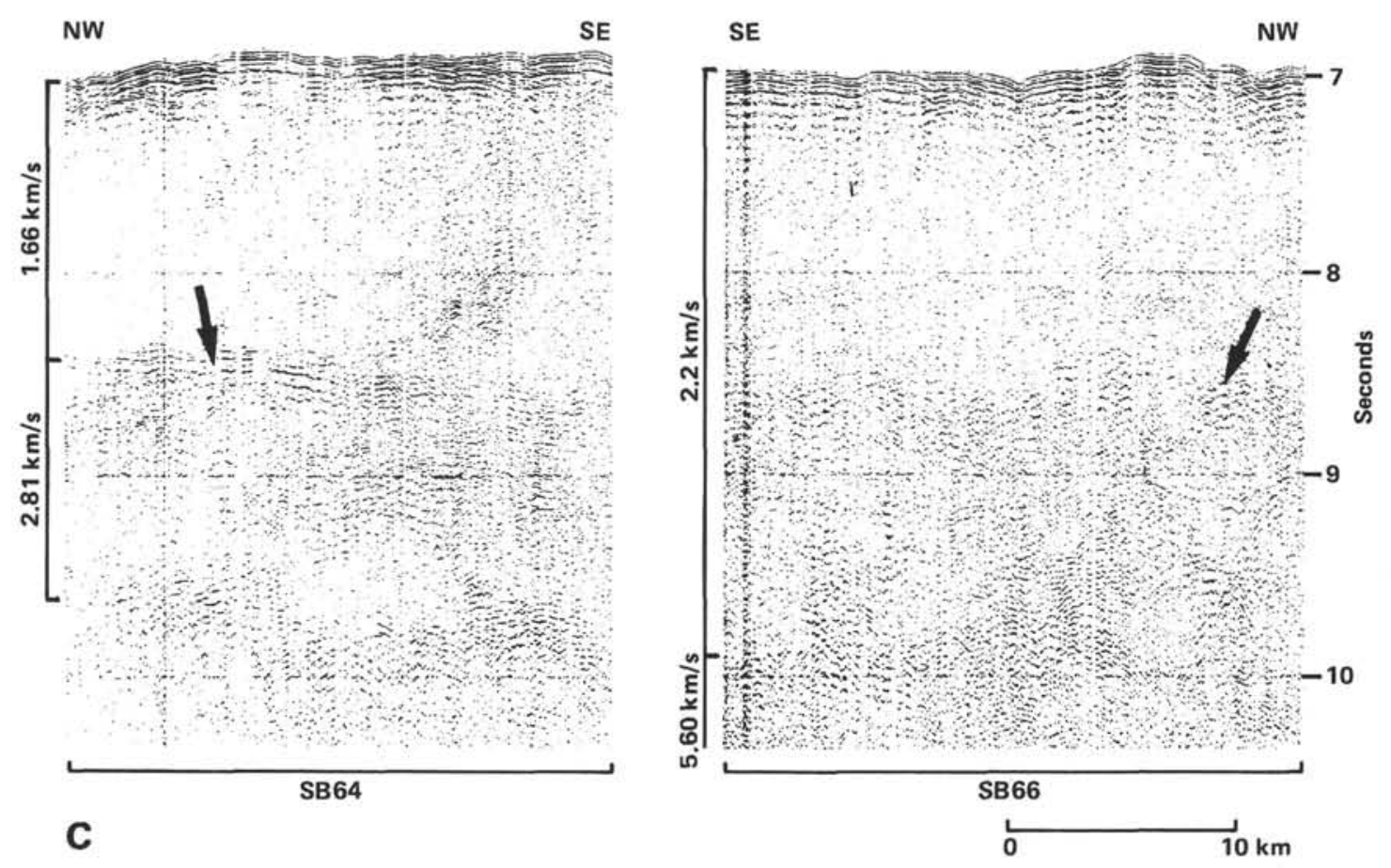

Figure 9. These two cross sections (along line C, Fig. 1) (C1602) have been run parallel to the deformation front. They show 3 seconds of sedimentary layers separated by the décollement [1.66 km/s above the décollement and $2.81 \mathrm{~km} / \mathrm{s}$ beneath (SB64)]. The undeformed layer overlies the oceanic basement [5.60 km/s (SB66)]. 


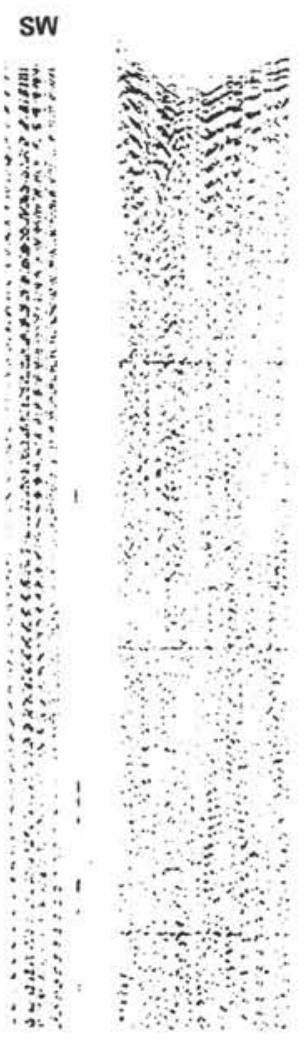

D

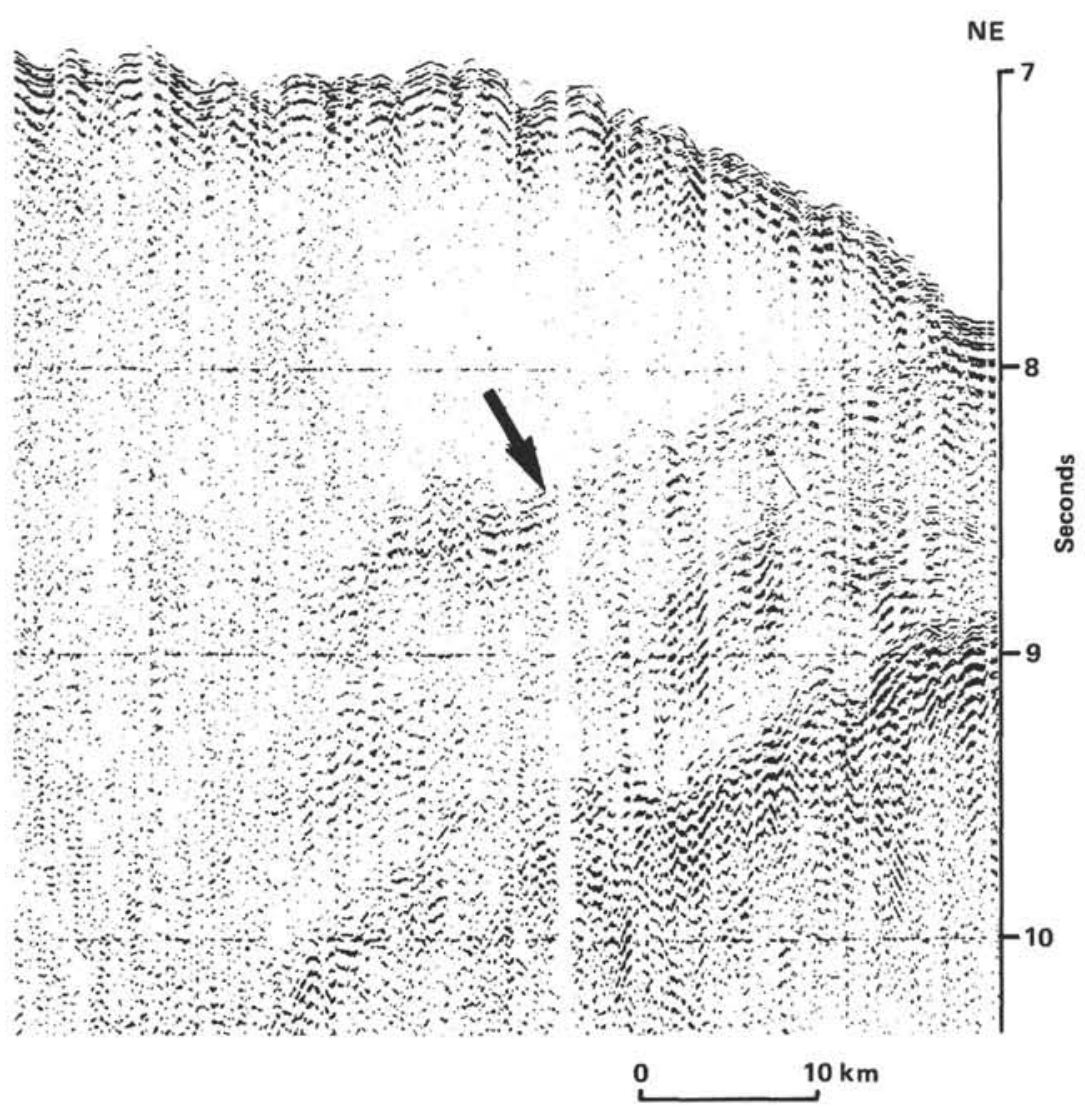

Figure 10. Seismic section along line D (Fig. 1). The décollement surface shown in this section, just south of the Barracuda Ridge, is very close to the top of the sedimentary sequence on the ocean floor. 


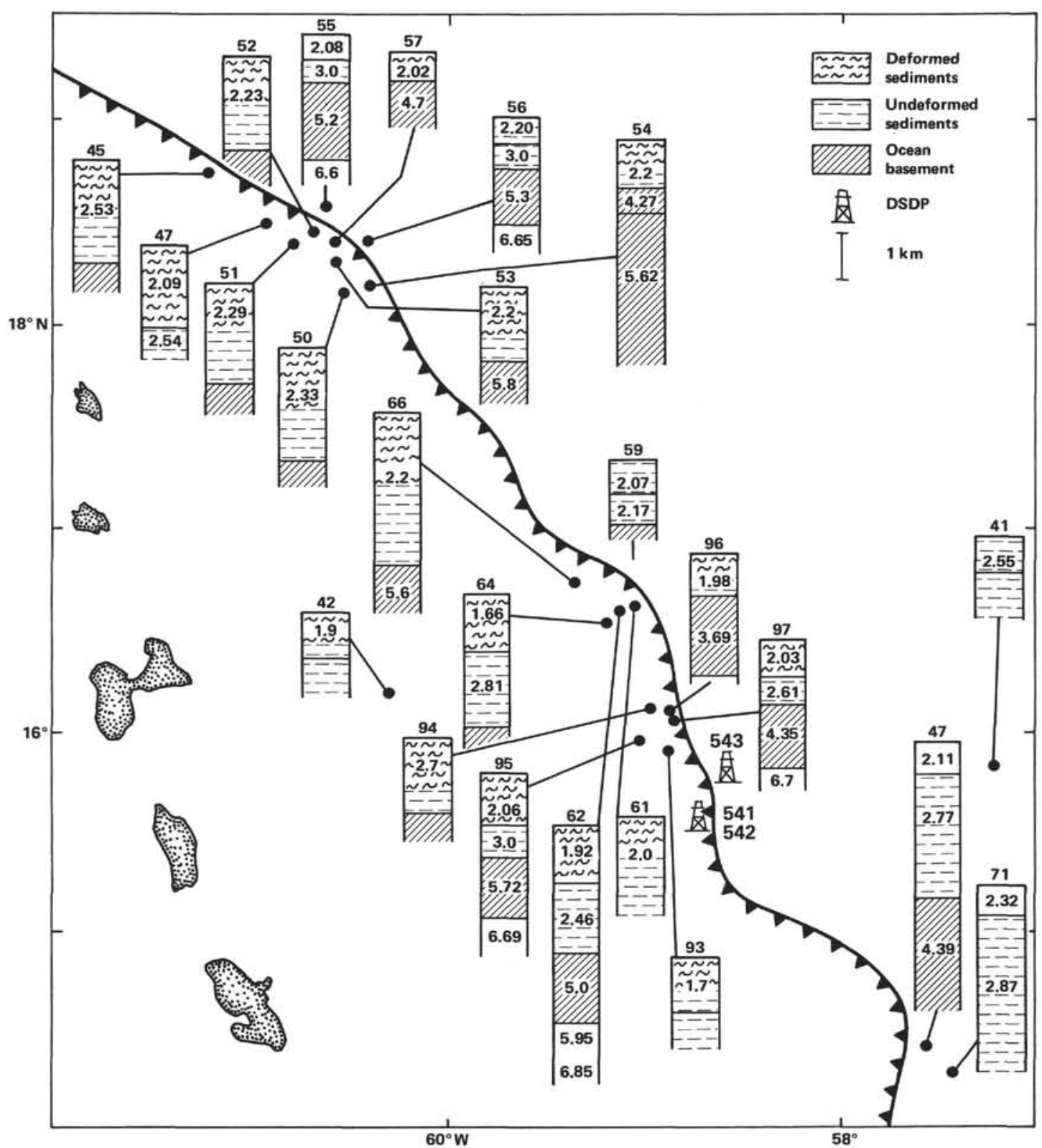

Figure 11. Seismic velocities determined from sonobuoys. Columns show the thicknesses of seismic layers interpreted as having constant velocities. An interpretation of a linear increase of velocity with depth in the sedimentary rocks will fit the data equally well. 

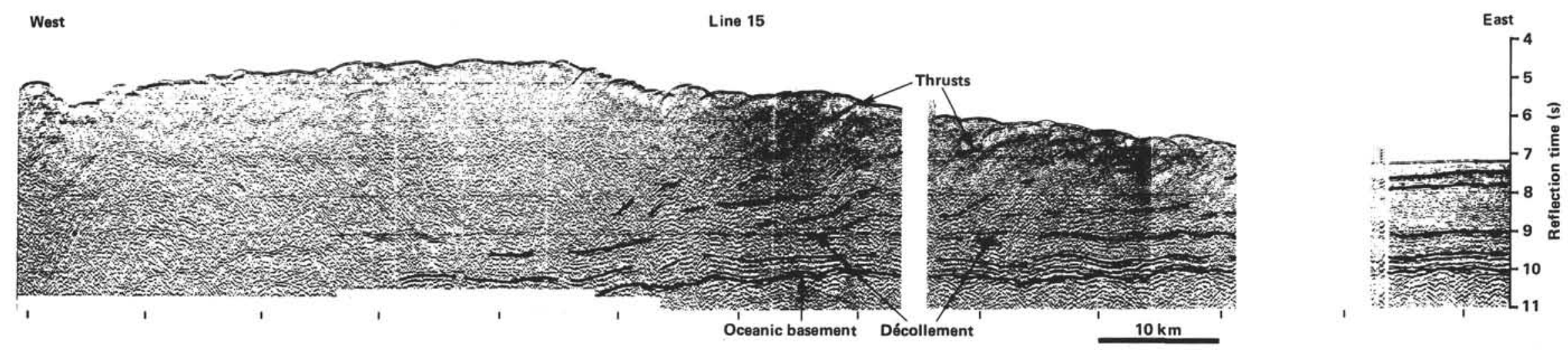

Figure 12. A 24-fold stacked seismic reflection section of line 15 from Conrad Cruise 1904. Position shown in Figures 1 (line E) and 14 (line 15 ). The oceanic basement is deep; the layer of undeformed sediments beneath the décollement is thick. The deformed layer is made up of stacked thrust sheets, generally shown by westward-dipping reflectors, which are often flexed.

SW

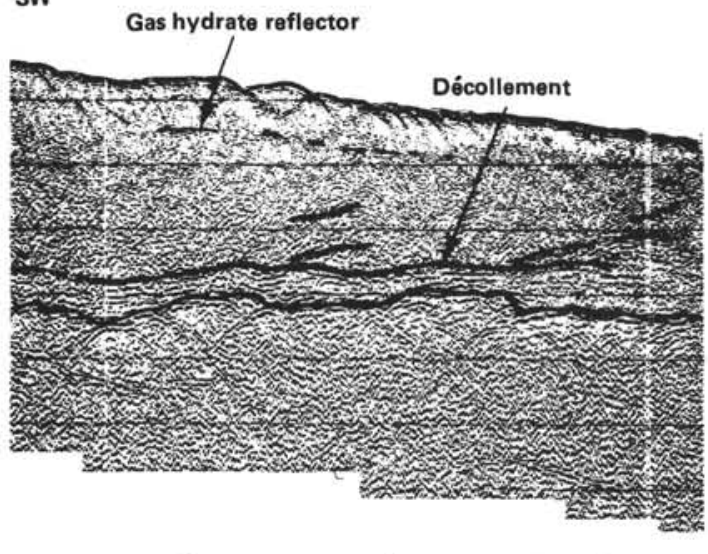

Line 14

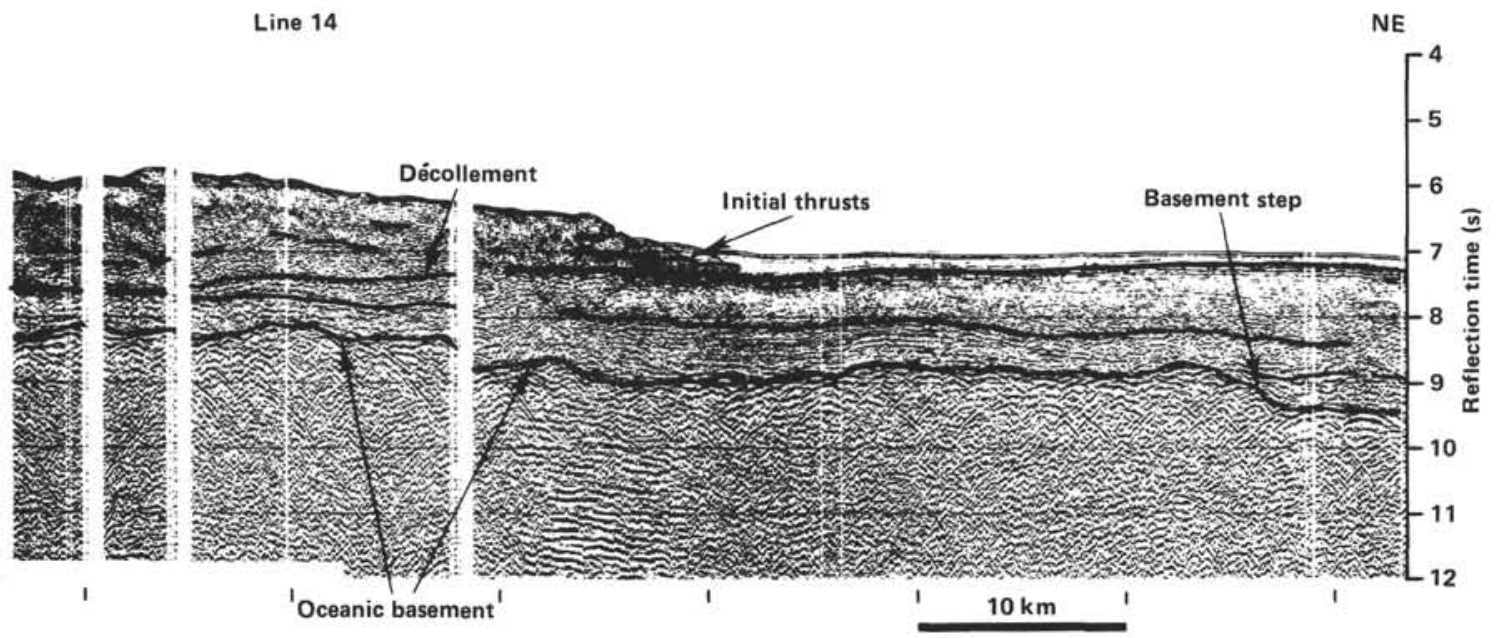

$10 \mathrm{~km}$

Figure 13. A 24-fold stacked seismic reflection section of line 14 from Conrad Cruise 1904. Position shown in Figures 1 (line F) and 14 (line 14). The basement rises step by step, leading to a thinning of the undeformed layer beneath the complex. The deformed layer shows incoherent reflection and a few westward-dipping reflectors. 

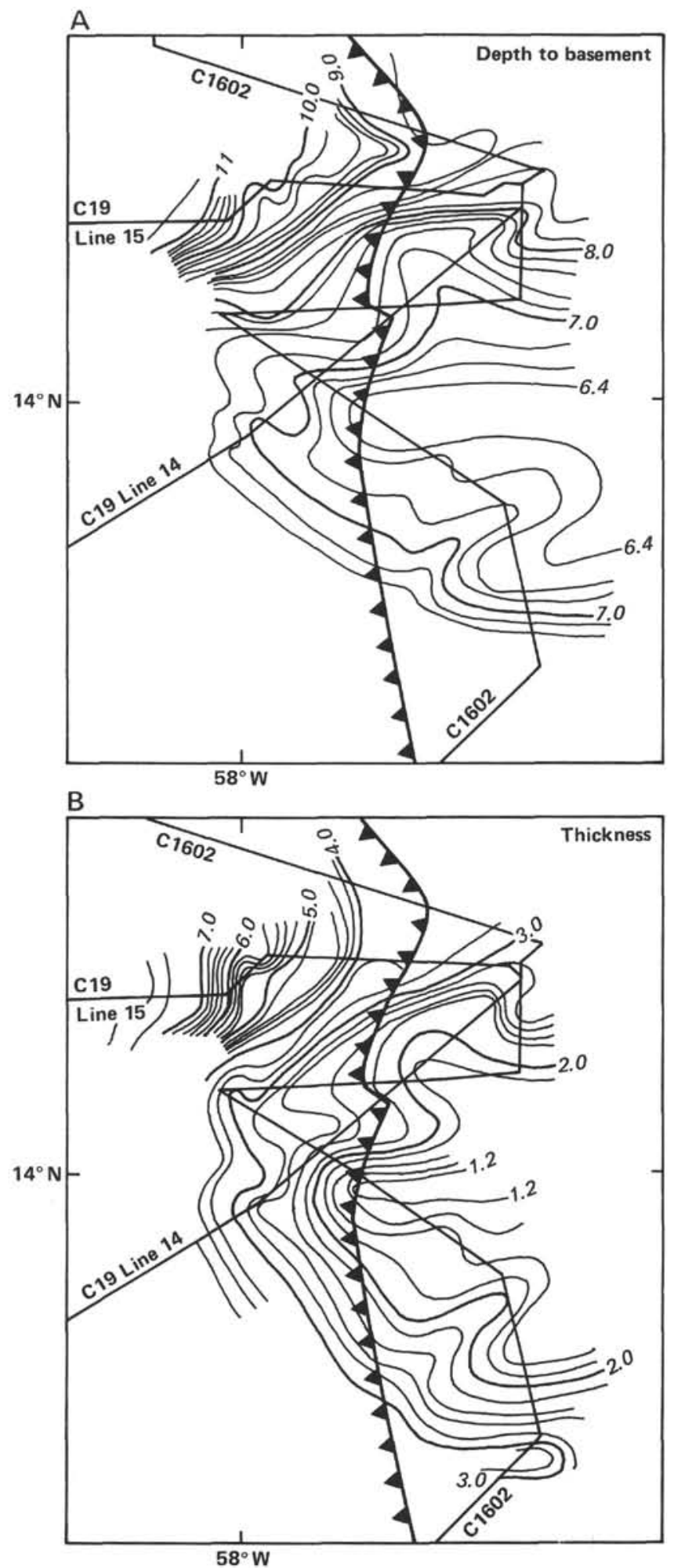

Figure 14. Maps of (A) depth to basement and (B) thickness for the area in Frame II, Figure 1. (Depth and thickness in km.) Seismic section $\mathrm{C} 1602$ and multichannel channel lines 14 and 15 were used to make these maps. Velocities from the sonobuoy results were used for conversion to kilometers. These maps show a ridge passing beneath the deformation front. Line 15 runs along a deep trough south of the Tiburon Rise. Line 14 is on the flank of the ridge. 